\title{
Body on the Border: Hannibal or the Popularity of Chopping up on TV*
}

\author{
Eren Ekin ERCAN
}

anadolu üniversitesi sosyal bilimler enstitüsü basın ve yayın anabilim dalı doktora öğrencisi eeercan@anadolu.edu.tr

\begin{abstract}
This study analyzes the historical context of the phenomenon of violence and the structure of the transformations it undergoes; particularly the transformation that unfolded with the transition from modernity to postmodernity. Hannibal is a series with intense scenes of bodily violence, and has a voting rate of 8.6 on IMDB with the votes of over a hundred thousand viewers. This descriptive study focuses on two aspects; i) discovering what kind of an ideological and historical dimension violence has and how this ideology is represented and transformed on the TV screen with postmodernity through the Hannibal series, ii) the exploration and theoretical discussion of TV violence through the transformation that has occured in how the body is approached. The most significant finding of the study is the coherent relationship between the body, violence and ideology.
\end{abstract}

keywords: $t v$, violence, ideology, popular culture, body, Hannibal

\footnotetext{
This article was shaped as a part of the course "Violence Studies in Media" conducted by Prof. Dr. Ömer Özer within the scope of the doctoral program of Anadolu University, Graduate School of Social Sciences, Department of Journalism. I would also like to thank Assoc. Prof. Dr. Incilay Cangöz for her elaborate reading of the article, her comments and advices.
} 


\section{Résumé}

\section{Le corps à la frontière : Hannibal ou de la popularité du dépeçage à la télévision}

Cette étude se donne pour but d'analyser le contexte historique du phénomène de la violence et la structure des transformations qu'elle subit; notamment celles qui sont survenues durant transition de la modernité à la postmodernité. Hannibal est une série télévisée avec des scènes intenses de violence corporelle, dont l'indice de popularité est élevé - 8,6 sur le site IMDB, avec plus de cent mille votants. Cette étude descriptive se concentre sur deux aspects; i) Comprendre la dimension idéologique et historique de la violence et comment elle est représentée et transformée à la télévision par la postmodernité à travers la série Hannibal; ii) Procéder à une exploration et à une discussion théorique de la violence à la télévision à partir de la transformation survenue dans l'approche du corps. Cette étude conclut à l'existence d'une relation cohérente entre le corps, la violence et l'idéologie.

mots-clés : télévision, violence, idéologie, culture populaire, corps, Hannibal

\section{Özet}

\section{Sınırdaki Beden: Hannibal ya da TV'de Doğramanın Popülerliği}

Bu çalıșmada şiddet olgusu, Hannibal dizisi üzerinden tarihsel bağlamda incelenmekte, geçirdiği kırılmaların yapısı; özellikle moderniteden postmoderniteye geçişle birlikte şiddet olgusunda ortaya çıkan değişim ve dönüşüm irdelenmektedir. Hannibal, her bölümünde beden başta olmak üzere yoğun şiddet sahnelerinin bulunduğu, IMDB'de yüz binin üzerindeki izleyici oylamasında 8.6 oy oranına sahip olan bir dizidir. Bu betimleyici çalışma iki boyutlu ilerlemektedir; i) şiddetin nasıl bir tarihsel ve ideolojik boyutu olduğuna ve postmoderniteyle birlikte bu ideolojinin TV ekranlarında nasıl cereyan ettiğine, dönüşüme uğradığına Hannibal dizisi özelinde cevap aranmakta, ii) TV şiddetinin, bedenin ele alınışında yaşanan dönüşüm odağında açımlanması, teorik olarak tartışılmaktadır. Çalışmanın en dikkate değer bulgusu ise beden, şiddet ve ideoloji arasındaki uyumlu ilişkidir.

anahtar kelimeler: televizyon, şiddet, ideoloji, popüler kültür, beden, Hannibal 


\section{Introduction}

"Bon appetite!"

Hannibal Lecter

The notion of flexibility, which manifests itself in production within the economy political background that is postmodernity's dynamo, comes into view as liquidity at the level of the subject's constitution. And the only place this liquidity reveals itself is the body. The state of existence, where Fordism yields to computer technologies and which only needs the subject's touch, is a state in which the modern body where the subject creates itself by negating itself disappears. For this reason, the subject becomes more sensitive to all kinds of narratives that reveal its own existence in this new "decentered" level where the subject reaches the power more indirectly but the power reaches the subject more directly (Sennett 2011: 54-62). The subject's strategies of existence and the new definitions, potentialities, treatments of the body in this context are reflected in the media contents as well. We are also reading the body which is acquiring more and more decorative and fetishized qualities as the only space and the only object where the subject constitutes itself. Therefore all the attempts towards the body in the societal sense requires a much more specific and exclusive approach. Especially if these attempts are constituted of images of violence that are aestheticized, edited and simultaneously watched by the masses.

In this context the popularity of violence in media lies not only in the content, form and degree of the violence in media texts, but also in who watches them and their current conditions. In other words, viewing and consuming a vicious genre of violence collectively cannot be explained only by the means of particularizing the representation of violence in media (besides, at the end of the day, representation derives its foundations or its feedbacks from what is societal, or it finds them in it) (Cheviron 2013: 21). Therefore, the first thing that should be examined in the field of media violence is not whether it is "harmful or harmless" or "whether the media contributes to the production of violence", but rather "why they choose to watch" (Trend 2008: 77) and concordantly "what is the nature of the pleasure that this choice provides".

This study aims to describe and discuss the transformation of popular culture and violence regarding the social topography on the basis of Hannibal series, by focusing on the concept of ideology with a point of view that harbours a psychoanalytic emphasis and historical references. In this context, first two seasons of Hannibal series are examined in parallel with the theoretical background presented in the first two sections of the study, the first section discussing mainly the historical aspects and the second section discussing the condition in contemporary societies. The phenomenon of violence is important in a macro dimension because it focuses on the debates regarding 
the transformations which first and foremost manifest themselves in a historical and ideological context with modernity and then with postmodernity.

\section{Popular Culture, Violence, Ideology: The Nature of Cathartic Topography}

The relationship between popular culture, its historical background and thus its ideology is quite important. In modernity, violence was generally implemented either as an excuse for prohibition or -although not very oftentruly as a requirement of the "social state" principle (Trend 2008: 9). But in both situations, the case in point is the power acting for "the benefit of the masses" or "for the masses". On the other hand, when preventing violence or any other "benefit" is in question, such a legalisation or enactment is normative and this normativity contains a campaign aimed at forming a general opinion. To capture this general opinion, the campaign should both lean on particular archetypes in a spatial sense and exclude certain things or social fractions as a matter of course. This exclusion, or rather inclusion by exclusion, is a structural result of the power's substantial claim.

The dynamism of the popular or the roots of tabloidization manifests itself with industrialization. Those texts, which became a current issue with serialized literary works and aimed at capturing the masses that flocked to the cities with generally accepted discourses, asserted themselves in newspapers by dealing with subjects such as the troubles of daily lives and romance (Ergül 2000: 56). The issues of identity and more importantly the ambiguity of memory that emerged in the subjects who flocked to the cities and thus had to cut their ties with the past could be filled precisely with suchlike contents and by capturing everyone. During the emergence of capitalism, this was the principal role assigned to journalism in the means of cultural and intellectual production. Those underpaid masses had begun sharing the same environment with people they did not know, and had faced an emotional and intellectual process where they felt smaller and smaller in the city's flamboyance and crowdedness. Identity has rendered itself liquid precisely with the emergence of the cities (Kellehear 2007: 191-201). The identity crisis in the public sphere was, in reality, a natural result of a semiological loosening that strived to be embedded and signified in the memory's denudated topography. Therefore, in the transition from one era to another, identity was precisely in a position of something that could be chosen, worn, bought and sold (Sennett 2002: 65-72). The ambivalent situation here was that it manifested itself as an agent of "concealment" on the level of the power even though this acquisition of identity was satisfying on a subjective level because the identity/ clothes "worn" by the members of the underclass usually consisted of identities/ clothes belonging to the upper classes. This "voluntary" lack of identity and memory, or, on the contrary, the pursuit of acquiring an identity/a memory was in reality a reflection of a symptom that was much more severe on the subject. 
Lacan claimed that it was Marx who discovered the symptom (Zizek 1991: 166), and that symptom lied at the heart of commodification.

\begin{abstract}
The commodity is, first of all, an external object, a thing which through its qualities satisfies human needs of whatever kind. The nature of these needs, whether they arise, for example, from the stomach, or the imagination, makes no difference. Nor does it matter here how the thing satisfies man's need, whether directly as a means of subsistence, i.e. an object of consumption, or indirectly as a means of production (Marx 1982: 125). ${ }^{1}$
\end{abstract}

Benjamin (2006: 66-96) had also identified the subject of capitalism with the flâneur through Paris and Baudelaire, regarding the cultural dimensions of capitalism. Benjamin (2006: 129), pointing out that a panoramic impressionist literature is prominent in Baudelaire, also calls attention to the fact that Baudelaire is not only a "desperate" carrier of lost memory, but also carries within himself the depressions of the new, and states that "Empathy is the nature of the intoxication to which the flâneur abandons himself in the crowd" (2006: 85-86). ${ }^{2}$ In this era where the memory had lost its nominals, journalism had assumed a crucial role. Regarding this, Benjamin states that "Newspapers flourish, along with magasins de nouveautés. The press organizes the market in spiritual values... (2006: 42)".

Horkheimer and Adorno (2002) draw attention to how the media(s) perform intellectual standardization in the creation of mass society in their book Dialectic of Enlightenment, where they expose how the media that they define as "the culture industry" functions on the axis of economy-politics-ideology. What is important here is that, this does not constitute of a relationship that can simply be described as downwards. In addition to the factual ground created by the change that manifested itself as a priori regarding the mode of production, in a structure which spatially leans on the cultural ground where one is lost within the city, the subject's "hunger" to feel its own existence as mentioned above was rendering the subject sensitive and open to all kinds of memory and identity patterns with which it could signify itself. When the nominal is displaced, the subject, who now perceives life dichotomously ${ }^{3}$ within a pathology that contributes to its destruction as much as it creates its existence (Horkheimer and Adorno 2002: 178-179), begins an endless and negative construction of its selfhood. This construction bears a great resemblance to capitalism's endless practice of production and consumption. Because the memory itself means returning to the

1 In addition, Zizek (1991: 132) defines symptom as "the coded message in which the subject receives its own message from the Other in reverse form".

2 It is also possible to read this condition of the subject in the paintings of Caspar David Friedrich (1774-1840) which were produced at the same period.

3 Even though here the "subject" is used in a general sense, I believe that Beauvoir's (1989: 95) valuable contributions should not be left out, who emphasizes the man who views the world under a sign of duality and who always defines himselfs according to the Other by referring to the unity of patriarchy and capitalism. 
old, lost "amnesia" which is now way past us. In other words, for the subject, existence was synonymous with keeping itself on the level of phantasmagoria the commodity had already reached (Benjamin 2006: 36), and the subject falling back to a lower level meant falling into the pathology. On the other hand, Althusser, who stated that "Ideology is an imaginary assemblage, a pure dream, empty and vein, constituted by the 'diurnal residues' of the only full, positive reality, that of the concrete history of concrete, material individuals materially producing their existence (2014: 175)" saying that "ideology has no history" - by referring to the class society in general but not confining it to its limits - is again related to this. Therefore, the foundation of the popular culture emerges "from within, from below, not from above" both in terms of psychoanalysis and on the level of society (Fiske 1989: 25). And this "popular" contains within itself the ideological dimension to one degree or another by definition.

In summary; the cathartic dimension of the historical psychoanalytical background/condition, where the subject both consumes and recreates itself axiomatically through hallucinogen images, happens precisely in a suchlike cultural economy. Here, the primary role belongs to the media as was mentioned before. But in this case, a problematic such as "what is the point of examining the themes and contents of media" arises. At this point, it is beneficial to state that the context of the discussion above presents a structural condition regarding the early periods of capitalism. The dimensions of capitalism have become much more encompassing, especially with the initially national and then global economic manifestations of fordism and postfordism in the 1900's. In a way, the cathartic ${ }^{4}$ dimension and the contents of media are changing, and for this reason, examining the popular contents of media is of vital importance for understanding ideology's spatial condition. Because the potentiality of violence within the subject finds and reconstitutes itself repeatedly in the commercial and cathartic media variations of the popular, which lean on the basis of the historical ideological adventures of the industrial society's social dialectic and which are produced in accordance with their spatial conditions, seeking to capture everyone (Özer 2010b).

In addition, such an ideology where the material reality is now rendered abstract by the modern, does not trivialize the body, but, contrary to popular belief, brings it into question. Foucault's focus being on the body while he was working on modernity, sexuality and punishment was not a coincidence. The body has become the medium and the target of the power's spiritual enforcements, especially with the modern. So much so that, within the body, which is the sole object of production and discipline, the power was on the one hand "over the whole surface of contact between the body and the object it handles (Foucault 1995: 153)", and on the other hand was playing a leading role

4 This is used as a structural, pathological symptom as was defined above, rather than being one dimensional and one directional. 
on the bodily "penance" of all kinds of "desires", "imaginings" and pleasures (which may be called "prohibition" in general), and the "process of confession and guidance" through "the repressive hypothesis" (Foucault 1978: 19). And this role is becoming much more precise with postmodernity.

\section{Postmodern Limit(lessness) and The Bulging of the Body}

Postmodernity leans on a background which is much more important than the cultural, epistemological, ontological aspects found in the arguments of postmodernists and which is considered "classical" by them: political economy. The debates on postmodernity along with the texts declaring a break from the modern in a contextual sense emerging and escalating in the 80 's is one of the most important indicators of this.

Fordism, a Taylorist and Keynesian mode of production which emerged at the beginning of 1900s, was a mode of production that was mainly associated with modernity and the emphasis was on national production. The Fordist model, which fell into a period of crisis with the 1960s due to the troubles encountered by the industry, was giving its place to the postfordist model with the 1980's, along with a pro-globalisation discourse that focused on international production/ consumption. This economical concept, which was a much more severe and rigid manifestation of the scientific organization of labour, was paving the way for a new international division of labour with multinational corporations (Gartman 1998). In the context of ideology, the most important epistemic advantage of this global economic division of labour was the creation of the "common language". This language was on the one hand bringing local to the fore in parallel with the developments in the communication technologies ${ }^{5}$, and on the other hand carried within itself a homogeneous and radical language which crosscut all the local languages (and therefore their cultural contexts) laterally. It was taking its radicalism from its retrospective and purely critical structure that brought all the spaces of its modern history together in the present, and rendered nostalgia innate as a commercial and ideological strategy (Stauth and Turner 1988). ${ }^{6}$ When language and its historical contexts are considered, this was the only situation that rendered history or the past simulative, and in a sense, as something that had never happened. The memory of a suchlike language corresponds to something much more pathological within the subject; if we cannot speak of an experienced past, or if it has been revealed that the experienced past was a "pseudo-past", the subject has to be content with existing by mediating itself

5 Here, it would be wrong to locate technology as the leading actor. As Jameson (1984: 77) stated referring to Marx "technology is, however, on the Marxist view the result of the development of capital, rather than some primal in its own right." Therefore, what is emphasized here is not the technology itself, but the "new" ideological climate it caused as a structural outcome of its possibilities.

6 For a discussion that may be considered more "up to date" on the axis of globalisation and language, see Morley (2006). 
through the remaining narratives (Sarlo 2012: 82). The prefix "post-", used for defining the modern's condition in our day, coincided with such a symptom in a much more precise manner regarding its characteristics that were mentioned in the first section. In other words, the indicators were becoming liquid and the postmodern subject's condition who was struggling to give meaning to its existence within these liquid indicators was a much more "advanced" and "late" phase of its condition in modernity (Jameson 1984). "Historical memory is held in safe keeping" and history is, again, written by victors, but this time with the aim of completion (Bauman 2005: 6). The central position in the modern architecture of power was consolidated, and now the subject would reproduce itself by fetishizing this kind of an "objectless" object of power:

It consists not in demonstrating that the game works without an object, that
the play is set in motion by a central absence, but rather in displaying the object
directly, allowing it to make visible its own indifferent and arbitrary character. The
same object can function successively as a disgusting reject and as a sublime,
charismatic apparition: the difference, strictly structural, does not pertain to the
"effective properties" of the object, but only to its place in the symbolic order
(Zizek 1991: 193).

In a sense, this was a condition where the modern era's body became much more bulged, because, as Foucault (1995: 29) stated, it meant that the subject waived its own priority in a much more precise manner. In this postindustrial phase, the body was now not even an alienated object of production. In a society that evolved from production to consumption, the body was the sole remaining stage of the spirit's possibilities of existence. But at this point, it is of vital importance to point out that what seems to be Bergsonian, is in fact the anti-Bergsonian condition of the body itself. That is to say; rather than being an object that had to be procured in order to satisfy the needs as mentioned by Bergson (1991: 198-199), the body had become the need itself because it had lost its function. In other words, the deconstruction and abstraction of the body and the material world with the post-industrial phase was actually the main thing that kept it on the agenda, rather than disregarding it (Butler 1995: 51-52). The increase in the use of body in popular culture, and especially the slasher films emerging with the 70 s and gradually being more in demand throughout the 80s and 90s were, again, results of this. The modern body, which the power focused on spiritually, was taking on an opposite function in the "decentralized subjectivity" culture of postmodernity (Habermas 1987: 94), and was becoming a fetishized object which the subject deciphered to make its existence accepted -and of course, to accept it- on the stage of power. The body was a sacrifice and an elegy for a claim of even the crippled historical residues being absent that was accumulated on a memory abandoned a long time ago.

The nature of ideology which emerges from the inside with the statement "to be made into popular culture, a commodity must also bear the interests of the people (Fiske 1989: 23)", takes place in this manner when it comes to the 
body. While the body was, on the one hand, the target of tearing down all sorts of power (Eagleton 1996: 71), on the other hand it was the centre of existential satisfaction where the cathartic spiritual function was carried out only as an other through the power (Pacteau 1994: 148-149). In a situation like this, the ideological function of popular culture demonstrates a dichotomous character: While the first aspect of this character "clasically" reflects the existent, the other aspect which has in fact been "new" for a long time reflects those "classical things" by devaluating them, by substituting their kitschic character as much as possible. ${ }^{7}$ This "new" dimension of popular culture that differs from the modern cathartic dimension and comes into the picture with postmodern popular culture lies in its suggestion, that rather than disappearing, the modern subject can escape this disappearance by consuming. Similarly, nostalgia itself was becoming the consumption of things that were torn to pieces and brought to the present, as opposed to its utopian view which is about breaking away from the existing place, geography, space and/or time and going to the things themselves (Jameson 1994: 85). Therefore, the subject was confined in the borders of the present in a much more precise manner. In the postmodern era, the plurality of the aesthetical and not so important variations of slaying which the violence in media leans on is a result of a suchlike pathology, or "demand". At this point, violence is first and foremost ideological; because it is already popular, and is inherent in the subject. Here, the media's role is as simple as satisfying it.

\section{Hannibal: The Archaic and Anachronic Representation of The Modern}

The show's first season aired on NBC in 2013 and second season which is now completed aired on 2014, both seasons consisting of thirteen episodes. Hannibal has proven that it caught on with the viewers with its 8.6/10 IMDB score ${ }^{8}$ with the votes of over ninety thousand members.

Trend (2008: 12) points out that, in a media text, the victim/victims of violence are just as important as the character/hero perpetrating violence and how he/she is perpetrating it, and from this point of view, he emphasizes that we should take a look at who the audience of violence is. Therefore, why is a series watched, where in every episode violence is at its peak, cutting, chopping and slicing is moulded with imagination and aesthetics, and people are made ingredients of dishes from different geographical areas and different cultures and are eaten cannibalistically? Here, we are faced with two areas of emphasis regarding form and content. These are; the dimension of form which is extremely static and which renders the audience a mere spectator with the strictest sense of the word in parallel with being supported with metaphorical elements, and the dimension of content where criminal events are supported with dialogs involving

7 Here, findings and observations of Gans (1974) about the position of classical or high culture within the "new" -in the sense it was used here- popular culture in the context of supply-demandclass in his work about popular culture and high culture are very important.

8 http://www.imdb.com/title/tt2243973/?ref_=nv_sr_1 (Date of access: 11.11.2014). 
coldblooded aphorisms, and characters and events/situations are patterned throughout the course of the series. Because the first one is rather technical and might only be meaningful for the readers who watched the series, in this study I generally chose to focus on the second dimension.

The first thing that should be remembered about the Hannibal character is that he is one of the results of the World War II. Being unable to protect his sister after their parents were slaughtered in the war and losing her as well, it is important to keep in mind that Hannibal is a character that carries such a destruction, chaos and eclipse of reason in his memory. The reason of the high viewing rates of Hannibal is -as will be discussed in detail throughout this studyfirstly due to him being the alter of our age.

The show's basic dramatical foundation consists of two characters; the first one is Will Graham, whose ability for empathy is on a maximum level and who helps catch the criminals by putting himself in the murderers' place in the crime scene, and the second one is Will Graham's psychiatrist Hannibal, who on occasion stands out with an emphasis on sympathy but an emphatic mood almost never comes across. Hannibal also offers FBI and Will Graham advice for solving cases throughout the first two seasons. Yet no one can be persuaded that he himself is a killer as well - apart from Will Graham who realizes this at the end of first season. In other words, Will Graham cannot persuade anyone even though he realizes that fact. Why is that? Why cannot Hannibal be caught as the one who is really responsible of all those murders, why does he go unnoticed? Because Hannibal is the modern nobody. A language that can contain this many locals within, especially with the globalized characteristic of the public sphere, can only create itself with a symbolization which structurally embraces everybody. Nobody has a problem as long as you satisfy the normal representatively within those symbolic exchanges of language, which are easily received by everyone and which are now neither local nor universal (Vattimo 2011). Hannibal is not noticed precisely for this reason. His clothes are neat, he has a clean speech, he is very competent on knowledge, history and art. He has no performance that could attract public attention. This is a precise indicator of how easy it is for a modern subject to hide within the postmodern language. In other words, Hannibal "attempts to fill out its constitutive lack by means of identification, by identifying itself with some master-signifier guaranteeing its place in the symbolic network (Zizek 1991: 163)". Yet with one difference, he does it with the very absence of it, fitting with the criticism of the postmodern theories directed on modern public identities for being normativising and standardizing. Such an inversion is an agreement shared by all the viewers, of reaching a much more essentialist, archaic modernity through Hannibal that even surpasses the modern itself; it is the deconstruction of deconstruction on screen. Moreover, this is the dominant dramatical element which originally makes the series interesting for the audience and which constitutes the dynamo of identification. 
On the other hand, this nobodiness of Hannibal functions in two directions: While the first one presents an identification of identity that annihilates, reduces the local which was put to the fore by global capitalism within the mentioned context to a nonentity, the second one renders such a situation insignificant on the level of slaughtered subjects. While Hannibal's reception of the body is through the eyes of a modern (or, more specifically, a Foucauldian) power, he once again reinforces this by bringing the body into question with its most violent possibilities in parallel with the aesthetical and iconographic choices of slaughtering the body. The body is not rendered insignificant as was presumed; on the contrary, the body is freed through Hannibal from "appearing to be in some sense there" - it now exists there (Butler 2007: 155). The body not going to waste and the parts that were cut away separately from different people being cooked meticulously, being shared with friends on the dinner table as in certain belief systems that could be called primitive, the conversation being constructed in terms of the geographical and mythological representations of that night's dish are important indicators of this. The body that was cut into pieces come together within other subjects and its qualitative existence is acknowledged precisely through its modern and quantitative value(ation).

At this point, referring to Will Graham, another important character, and making a comparison between him and Hannibal would enable us to understand the role Hannibal plays better. First of all, Will Graham's practice at the crime scene is important. Because he, like an excellent ethnographer, can experience the local language by living it himself, and later on he can put it into words for others, in other words, he can make himself a "witness" or at least he can use this claim as a tool for capturing the criminal. The sentence he uses at every crime scene after this "emphaty session" is very important in this context: "This is my design!". On the other hand, Will Graham's capacity for empathy is on a very high level as was mentioned before and later on in the series this ability of his causes him paranoia and hallucinations that is brought on -with the help of drugs given to him by Hannibal- by being in dilemma between whether he might be the killer and sensing who the killer is, as well as an array of schizophrenic reactions. This witnessing is in reality assumed erlebnis (Agamben, 1999). ${ }^{9}$ Because whereas the location is the same, time, even though it involves what comes later, summons the space into the present and experiences it in this way. Rather than being an attribution of a single and linear time, the present is deconstructive

9 Pointing out that there are two uses for the word "witness" in Latin, Agamben (1999: 17) states that they are testimony and superstes. Testimony is a more "secondary" witnessing experienced by a third person who is not one of the parties of the event. Superstes is a person or people who personally experience the event. Similarly, the words erlebnis and erfahrung are used for witnessing and experience in German. While erlebnis depicts people who personally experience the event, erfahrung expresses a more neutral, passive position which may be called "secondary". Bauman (2009) states that: "Other people's experience cannot be truly learned as experience; in the end-product of learning the object, one can never seperate the original erlebnis from the creative contribution of the subject's imaginative powers. Experience of others can be known only as a processed, interpreted story of what the others lived through". 
because the past is summoned and carries within the claim of being analysable and understandable. This is the postmodern thinking itself. What is ideological about it is, that it does all these in the present, it idles away the present with it, in other words, it skips the present. And the present is Hannibal himself. If we were to put this in a Jamesonian (2002: 17-58) manner, Hannibal is the condition of the modern and he is not subjective; and the eccentric and subjective dimension of Hannibal's position lies in the way he narrates the subjectivity's attitude towards itself in his anachronic position.

Again, two questions are of vital importance here: Why does Hannibal establish a dialog with Will Graham instead of killing him? Why does Will Graham's capacity for empathy lose its function when it comes to Hannibal? Here, two fundamental breaks, collisions regarding the subject that came into existence with the modern society are in question. The romantic and emphatic Other of Hannibal's homogenous existence has the potential of being understood only by Will Graham. This is the reason Hannibal has chosen Will as the one who can understand his Other and therefore says to his own psychiatrist: "I met a man much like myself... but I'm not interested in being his friend... We see the world in different ways, yet he can assume my point of view."10 Will and Hannibal are alters of each other. This is also the basis of Graham's capacity of empathy falling short when it comes to Hannibal. But Will discovers this at the end of first season and Hannibal makes sure he is put into prison with the plot he had been laying since the day that they met -just like he does to everybody- to guarantee his own safety. Will is angry at first, but then, realizing that this "abstract" capacity for empathy cannot bring him down, he starts acting like Hannibal. We watch some people disappear and we think Will killed them. But all this is a trap Will and $\mathrm{FBI}$ planned together to catch Hannibal. Even though Hannibal seems like he is oblivious of this plan as a part of the drama, he performs a real slaughter on the last episode of the second season. He slays almost everyone. Hannibal overcoming like this, which no one anticipated, is a blow on "ideological fantasy".

\footnotetext{
Where is the place of ideological illusion, in the 'knowing' or in the 'doing' in the reality itself? At first sight, the answer seems obvious: ideological illusion lies in the 'knowing'. It is a matter of a discordance between what people are effectively doing and what they think they are doing - ideology consists in the very fact that the people 'do not know what they are really doing', that they have a false representation of the social reality to which they belong (the distortion produced, of course, by the same reality) (Zizek 2008: 27).
}

Hannibal defeating Graham is made possible by the Abigail character that has a very important role in the series. Abigail is the daughter of a serial killer who was killed by Graham at the beginning of the series and she is in herself the object of the relation between Hannibal and Graham. While Graham approaches her with feelings of guilt for killing her father, for Hannibal, Abigail

10 Season 1 Episode 8, 27:30-29:00. 
is the substitute of his sister Mischa whom he lost when he was a child. Above all, Abigail is the reason Graham is unable to kill Hannibal at the end of second season. Abigail is shown to be dead/murdered somewhere along the series but she is not actually dead. Hannibal hides Abigail and when he brings her out again Graham is shocked, therefore defeated by Hannibal. The important thing here is that Graham's hallucinogen character with which he presumes he deceived Hannibal is defeated by a common object of trauma from the past that is revealed by Hannibal. In other words, this is the pacification of the knowledge/identity that was constructed based on action/performance and one is -"naturally"- very sure of it being there, by revealing the knowledge embedded in its object that one is sure of its material absence being there. Hannibal defeating Graham is Erlebnis defeating Erfahrung, or the subject that stays connected to cogito defeating the subject that stays connected to cogito me cogitare. ${ }^{11}$

Hannibal, who only listens to classical music, who makes drawings as a hobby, who does not speak much but when he does he talks with aphorisms, who does not make his high culture, his subjective memory and his problems public is modern, and this anachrony is the source of Hannibal's popularity which legitimizes his violence for the audience. But it is necessary to examine this in more detail on an ideological axis focusing on the audience.

\section{Watching Hannibal: Existing by Disappearing or Ideology that Aims at Itself}

Sontag (2005: 8) points out that whether it is an object, a subject or something else that is being recorded, recording leads to that thing's immortality. If the thing being recorded is the death, killing, destruction itself -as in the Hannibal series- and this is watched in masses, does this statement still apply? And more importantly, what kind of an ideology does this carry within?

Media is an indispensable actor in our social lives. Especially when the things that happen on TV and their roles in the construction of subjects are considered, the situation becomes much more critical. While on the one hand media in general and particularly TV is a medium of looking at what is happening over there and experiencing identification, on the other hand it is a playground where the subject determines the answer to "where am I" and then evaluates, smoothens, and establishes its social self accordingly (Trend 2008: 97). Whether this will the subject has for staying inside is related to public, private or economic concerns, it also means the repression of certain things for the subject. The repressed seep into the contents of the screen over time

11 Cogito means "think(ing)"in Latin, where Cogito me cogitare means "I am thinking that I am thinking". Those conceptualizations are especially important with regard to the discussions about the "tension" between the arguments of modernity and postmodernity on the concepts of subject, subjectivation and subjectivity (Jameson 2002: 47-48). This can also be seen in Zizek (2008: 217). 
and diversify by watching each other. A media content's depth that coincides with the societal and its excellence, lies in it being aware of itself and this is firstly economical (Özer 2010a). Therefore, the public does not stay in the public sphere for the audience; at night it seeps into the private sphere through the screen and manifests itself. The audience is still a consumer who consumes the advertisements -for whatever reason- in his/her private sphere. Thus, the nature and popularity of the violence in media lies in the economy between the media content's dedication to increasing the audience by capturing the archetypes of the society and the advertisers' -natural- wish to be visible in that content. This societal body is an infinite body which is beaten, cultivated and needs to be healed constantly. ${ }^{12}$ Like Freud's (1998: 161-164) "beaten child". The things this child encounters while growing, about the self that he/she can hardly remember, settles on an ambiguous context through encountering variations of violence. Then the child watches real images of violence, even if he/she is "disgusted" by them. Whether or not he/she encounters such a scene growing up, he/she still constructs the fantasy of "the beaten child" in a masturbative manner. Whereas the violence in TV presents all sorts of this violence fantasy in a multiangular and aesthetic way without the audience tiring him/herself over it. But from the viewpoint of the audience there are much more patterned determinative elements in Hannibal.

As was mentioned before, Hannibal sees the character of Abigail as a substitute for his dead sister Mischa. There is even a scene where he cries while he makes a connection between Abigail and Mischa. But, instead of letting a substitute of someone who caused such traumatic effects on his memory cripple him, he chops her up and kills her. This is both a loyalty to the uniqueness of the symptom, and acceptance of the situation and letting oneself go free (and heal) by practicing a cathartic method on oneself in order to get rid of the symptom. In an ideological context this is polysemic and it is polysemic precisely because it is self-inflicted. It is self-inflicted because he is now on the border, Hannibal is close to being caught; he thinks he can keep on existing by destroying the last remnants of his own memory. Burning the diaries he had been keeping all his life and all other records is again a result of this. But this is not an end because his existence, which he held on equilibrium somehow, surrenders to a much bigger and restrictive symptom, instead of breaking free by killing that little symptom: A never ending escape. Just like Zizek's (1991: 26-29) "corpse that would not die". This approach, which may seem extraordinary and radical to the audience, actually renders the ideology immanent in the complete denial that originates from the audience being satisfied with the fantasy of "beaten child" knowing that he/she will not/cannot be beaten in real life, or that he/she can never know exactly what caused this fantasy and even if he/she learned what caused the fantasy he/she would still not know what to do with it. If a conceptualization is necessary, this is imago mortis.

12 Here, it is important mentioning George Gerbner (1963; 1966; 1967; 1974; 1985) and his Cultivation Theory. 
Imago Mortis is "the concept that allows us to move from "similitude" to "reality", and thus to experience a mediated death as though it were unmediated (Kinch 2013: 10)". The cathartic state (which is the field of "typical" representation studies) created through similitude is moved to the second level of reality and this is where it really gains its function. In Hannibal's specific case, this is the audience identifying with a recorded experience and sacrificing the body as a victim in a semi-religious, mythical context (Eagleton 2014: 177). Watching the recording of something that actually died a long time ago be slaughtered through the Other (on screen) is the subject's memento mori, because the audience participates in it and this participation is an approval of what is determined on the screen by the audience (Sontag 2005: 11). The subject is rendered the perpetrator of his/her own self, slaughtered by his/her own Other. This is the pornographic spectacle of death where the "antinomy of gaze and view (Zizek 1991: 110)" disappears. Hannibal, who comes into existence in the audience's nostalgic present, is the chopper of the societal body. The "claims of reason" ultimately being sacrificed "to the cause of ideology" (Eagleton 2014: 141) is the ideological eccentricity of Hannibal, because this is viewer's ideology that aims at itself through Hannibal. Ideology comes into existence by unveiling itself and those hallucinogen bodies are chopped on the border within the compass of a mutual agreement. Just like Hannibal says: "So much about this feels like a dream. Dreams prepare us for waking life. It's one thing to dream; it's another to understand the nature of the dream. You're waking up to who you are. That's all you need to understand". ${ }^{13}$

\section{Conclusion}

How violence takes place in the media and especially on TV is as important as the extent or scale of violence. The collective panic Orson Welles' radio drama The War of The Worlds (1938) caused has given its place to a situation where every kind of violence is watched "with pleasure", is conversation material, and moreover, the killer is admired. The vital question to be asked regarding the scale, variations and forms of violence which is increasing both in real life and media content is "what is it that is gradually changing/increasing/decreasing?" From this aspect, violence appears before us as the reflection of an existing reality as an other on the screen.

Another matter that is overlooked when the problem is being formulated is the relationship between violence and ideology. The screen is generally approached with a "modern" perception from above, and the agitation of the audience's "activeness" is favoured over the determination of the problematic with utmost clarity when it comes to the audience. There is an extremely historical and structural "crisis", as this study attempted to present, and it is not just about TV (Halloran 1983). The Hannibal series is one of the most important indicators of this. A series where people are chopped up, dismantled, presented

13 Season 2 Episode 12, 16:30-17:30. 
as aesthetical meals which are indicators of conversations shared with friends should not only be read as a consequence that was created by the media and is watched by "passive audiences". Of course, media has a dominant role as the glue of masses, but as was mentioned above, the fact that contents that were "disgusting" thirty years ago are today "common" mise en scene spectacles on screen demonstrates the inevitability of studying the concept and the phenomenon of ideology precisely in relation to violence. Otherwise, even more heavy viewers will be cultivated, not only quantitatively but qualitatively, and the problem will become inextricable.

Another dimension of the series that stands out is about the body. Body becomes the goal precisely because of its instrumentality, and it is constantly subjected to fragmented evaluations. Body is approached within a space filled with the tension between references of value which have anthropological and mythical themes and a biologism where the body's totality becomes insignificant, where all the cold blooded violence happens. These dead bodies which are displayed on the screen are, in a sense, objects where the potentiality of existence, which had become unnecessary and insignificant with the contemporary economy political views, is rendered valuable again through iconographic opportunities. The origins of the radical reception of every alternative and aesthetical attempt directed at those valuable bodies which are practically the batteries of Fordism should be sought here. If we are to rephrase it from an opposite perspective, in our present day, associating the reception of violence scenes as "common" only with media and media texts is causing difficulties regarding a clear assertion of the problem. Therefore, in the series, violence implemented on the body is not merely violence; it is also a function that constitutes the dynamo of the narrative and enables the story to unfold, a function of central importance for achieving the goal of the narrative. In this context, the pleasure of watching the violence implemented by the Hannibal character manifests the popular border where ideology and the body intersect in a destructive manner.

\section{References}

AGAMBEN Giorgio (1999), Remnants of Auschwitz: The Witness and The Archive, New York, Zone Books. ALTHUSSER Louis (2014), On The Reproduction of Capitalism: Ideology and
The Ideological State Apparatuses, New York, Verso.

BAUMAN Zygmunt (2005), Work, Comsumerism and The New Poor, New York, Open University Press.

BAUMAN Zygmunt (2003), Liquid Love: On The Frailty of Human Bonds, Cambridge, Polity Press. Available at: http://books.google.com.tr/books?id=-Ww cTrULFt4C\&printsec=frontcover\&dq=liquid +love+bauman\&hl=tr\&sa=X\&ei=DU 
N2VIH5H_GP7AaW6YHwBg\&ved=0CBwQ6AEwAA\#v=onepage $\& q=$ liquid $\% 20$ love $\% 20$ bauman\&f=false

BEAUVOIR Simone de (1989), The Second Sex, London, Jonathan Cape.

BENJAMIN Walter (2006), The Writer of Modern Life: Essays on Charles Baudelaire, Harvard, The Belknap Press of Harvard University Press.

BERGSON Henri (1991), Matter and Memory, New York, Zone Books.

BUTLER Judith (1995), Contingent Foundations, in: Nicholson $L$ (ed) Feminist Contentions: A Philosophical Exchange, New York, Routledge, 35-59.

BUTLER Judith (2007), Gender Trouble: Feminism and The Subversion of Identity, New York, Routledge.

CHEVIRON Nilgün Tutal (2013), Televizyon ve İçimizdeki Şiddet (Television and the Violence Within Us), İstanbul, Kırmızı.

EAGLETON Terry (1996), The Illisuons of Postmodernism, Oxford, Blackwell.

EAGLETON Terry (2014), Culture and The Death of God, London, Yale University Press.

ERGÜL Hakan (2000), Televizyonda Haberin Magazinelleşmesi (Tabloidization of Television News), İstabul, İletişim.

FISKE John (1989), Understanding Popular Culture, New York, Routledge.

FOUCAULT Michel (1995), Discipline and Punish: The Birth of The Prison, New York, Vintage Books.

FOUCAULT Michel (1978), The History of Sexuality: Volume 1. An Introduction, New York, Pantheon Books.

FREUD Sigmund (1998), Psikopatoloji Üzerine (On Psychopathology), Çev. Selçuk Budak, Ankara, Öteki.

GANS Herbert J. (1974), Popular Culture and High Culture, New York, Basic Books.

GARTMAN David (1998), "Postmodernism; or, The Cultural Logic of Postfordism?", The Sociological Quarterly, 39 (1): 119-137.

GERBNER George (1963), "Communication and The Humanization of Homo Sapiens", AAUW Journal, (56): 102-104.

GERBNER George (1966), Images Across Cultures: Teachers in Mass Media Fiction and Drama", The School Review, (74): 212-229.

GERBNER George (1967), Mass Media and Human Communication Theory, Frank E. X. Dance (Ed). Human Communication Theory: Original Essays, New York, Hot, Rinehart \& Winston, 40-60. 
GERBNER George (1974), "Communication: Society is The Message", Communication, (1): 57-64.

GERBNER George (1985), Mass Media Discourse: Message System Analysis As A Component of Cultural Indicators, Teun A. van Dijk (Ed). Discourse and Communication: New Approaches to The Analysis of Mass Media Discourse and Communication, Berlin: Walter de Guyter \& Co, 13-25.

HABERMAS Jurgen (1987) The Entry into Postmodernity: Nietzsche as a Turning Point, in: Habermas J (Ed) The Philosophical Discourse of Modernity. Massachusetts, MIT Press, 83-106.

HALL Stuart (1999), Encoding, Decoding, in: Simon During (Ed) The Cultural Studies Reader, London, Routledge, 507-518.

HALLORAN James D. (1983), Kitle İletişimi: Şiddetin Belirtisi mi, Yoksa Nedeni mi? (Mass Communication: Symptom or Cause of Violence?), Oya Tokgöz (Ed). İletişim ve Toplum Sorunları: Kuram ve Uygulama, Ankara, Türk Sosyal Bilimler Derneği, 62-84.

HORKHEIMER Max and ADORNO Theodor W. (2002), Dialectic of Enlightenment: Philosophical Fragments, Stanford, Stanford University Press. JAMESON Fredric (1984), "Postmodernism, or The Cultural Logic of Late Capitalism", New Left Review, 146: 53-92.

JAMESON Fredric (2002), A Singular Modernity: Essay on The Ontology of Present, London, Verso.

KELLEHEAR Allan (2007), A Social History of Dying, New York, Cambridge University Press.

KINCH Ashby (2013), Imago Mortis: Mediating Images of Death in Late Medieval Culture, Leiden, Brill.

MARX Karl (1982), Capital I: A Critical of Political Economy, Middlesex, Penguin Books.

MORLEY David (2006), "Globalisation and Cultural Imperialism Reconsidered: Old Questions in New Guises", in: Curran James and Morley David (Eds) Media and Cultural Theory, Oxon, Routledge, 30-44.

ÖZER Ömer (2010a), Pazarda Şatışın Öyküsü: Medyada Sunulan Şiddeti Ekonomisi (The Story of Sale in The Market: The Economy of Violence Presented in Media), in: Özer Ömer (Ed) Medyada Şiddet Kültürü (Violence Culture in Media), İstanbul, Literatürk, 35-60.

ÖZER Ömer (2010b), Medyanın İdeolojik Şiddeti (Ideological Violence of Media), in: Özer Ömer (Ed) Medyada Şiddet Kültürü (Violence Culture in Media), İstanbul, Literatürk, 451-494. 
PACTEAU Francette (1994), The Symptom of Beauty, London, Reaktion Books.

SARLO Beatriz (2012), Geçmiş Zaman: Bellek Kültürü ve Özneye Dönüş Üzerine Bir Tartışma (Tiempo Pasado: Cultura de la Memoria y Giro Subjetivo Una Discusion), Çev. Peral Bayaz Charum and Deniz Ekinci, İstanbul, Metis.

SENNETT Richard (2002), The Fall of Public Man, London, Penguin Books.

SENNETT Richard (2011), Karakter Aşınması: Yeni Kapitalizmde İşin Kişilik Üzerindeki Etkileri (The Corrosion of Character: The Personal Consequences of Work in The New Capitalism), Çev. Barış Yııdırım, İstanbul, Ayrıntı.

SONTAG Susan (2005), On Photography, New York, Rosetta Books.

STAUTH Georg and TURNER Bryan S. (1988), "Nostalgia, Postmodernism of Critique of Mass Culture", Theory, Culture and Society 5 (2): 509-526.

TREND David (2008), Medyada Şiddet Efsanesi: Eleştirel Bir Giriş (The Myth of Media Violence: A Critical Introduction), Çev. Gül Bostancı, İstanbul, YKY.

VATTIMO Gianni (2011), "Ortak Dil Olarak Yorumbilgisi (Hermeneutics as Koine)", in: Küçük Mehmet (Ed) Modernite versus Postmodernite, 317-329.

ZIZEK Slavoj (1991), Looking Awry: An Introduction to Jacques Lacan Through Popular Culture, Massachusetts, MIT Press.

ZIZEK Slavoj (2008), The Sublime Object of Ideology, New York, Verso.

http://www.imdb.com/title/tt2243973/?ref_=nv_sr_1 (Date of access: 11.11. 2014) 
